Jurnal Ilmu Ilmu Agribisnis: Journal of Agribusiness Science, 9(1), Februari 2021

\title{
ANALISIS PENDAPATAN DAN TINGKAT KESEJAHTERAAN RUMAH TANGGA PETANI TEBU RAKYAT DI KECAMATAN BUNGAMAYANG KABUPATEN LAMPUNG UTARA
}

\author{
(Income and Welfare Level Analysis of Sugar Cane Farmer Households in Bungamayang Sub-District \\ North Lampung Regency)
}

Thomas Mayang Andriadi, Fembriarti Erry Prasmatiwi, Maya Riantini

Jurusan Agribisnis, Fakultas Pertanian, Universitas Lampung, Jl. Prof. Dr. Soemantri Brojonegoro No.1 Bandar Lampung, 35145,e-mail: fembriarti.erry@fp.unila.ac.id

\begin{abstract}
The objectives of this research were to find out the income of sugar cane farming, household income of sugar cane farmers, household welfare level, and factors that affect the welfare level of sugar cane farmer households in Bungamayang Sub-District. The location was determined purposively, considering that Bungamayang Sub-District has been the center of sugar cane production in North Lampung Regency. The number of respondents in this research were 54 farmers taken randomly. Data were collected in April -May 2019. The analytical method used for the first and second objectives was farm analysis, the third objective used Sajogyo welfare level analysis and the fourth objective used binary logit analysis. The study shows that average income of sugar cane farming is IDR23,161,313.80/hectare. Average annual household income is IDR44,295,593.33 and the contribution of sugar cane farming income to household income is 57.52 percent. Based on the criteria of Sajogyo, sugar cane farmer households are included in the sufficient category. Household income positively affects welfare level, while the number of family members negatively affects the welfare level of sugar cane farmers in Bungamayang Sub-District.
\end{abstract}

Keywords: farmer households, income, sugar cane, welfare level

\section{PENDAHULUAN}

Sektor pertanian memegang peran penting sebagai penopang pembangunan di Indonesia. Menurut Badan Pusat Statistik (2018), kontribusi sektor pertanian pada Produk Domestik Bruto (PDB) menempati urutan pertama, yakni menyumbang sebesar 13,14 persen dari jumlah keseluruhan PDB Indonesia atas dasar harga berlaku tahun 2017. Sektor pertanian terbagi ke dalam beberapa subsektor. Salah satu subsektor yang memberikan peranan penting bagi perekonomian adalah subsektor perkebunan. Komoditas perkebunan yang selama ini menjadi salah satu unggulan di Indonesia adalah tebu.

Provinsi Lampung memiliki peranan yang besar dalam memenuhi ketersediaan gula nasional. Hal ini dibuktikan pada tahun 2017, Provinsi Lampung berkontribusi sebesar 60,12 persen dari jumlah keseluruhan produksi gula nasional. Salah satu sentra produksi tebu di Provinsi Lampung adalah Kabupaten Lampung Utara. Sebagai sentra produksi tebu, produktivitas usahatani tebu di Kabupaten Lampung Utara masih tergolong rendah. Menurut Direktorat Jenderal Perkebunan (2017), produktivitas usahatani tebu Kabupaten 122
Lampung Utara di Provinsi Lampung berada pada posisi dua terbawah. Rendahnya produktivitas usahatani berpengaruh terhadap menurunnya pendapatan yang diterima petani dan kemudian berujung pada kemiskinan (Hudaya 2009).

Hampir 22 persen dari 612.100 jiwa penduduk Kabupaten Lampung Utara termasuk ke dalam kategori miskin pada tahun 2017 (BPS Kabupaten Lampung Utara 2018). Oleh sebab itu, potensi yang ada di Kabupaten Lampung Utara patut untuk dikembangkan guna mengentaskan kemiskinan. Salah satu potensi yang ada di Kabupaten Lampung Utara adalah komoditas tebu. Terdapat dua jenis kepemilikan usahatani tebu di Kabupaten Lampung Utara, yakni usahatani tebu milik perusahaan dan milik masyarakat.

Sentra produksi tebu di Kabupaten Lampung Utara adalah Kecamatan Bungamayang, di kecamatan tersebut terdapat sebuah BUMN yang bergerak di bidang agribisnis tebu, yakni PTPN VII Distrik Bungamayang. Tanaman tebu yang dibudidayakan terdiri dari kriteria plant cane (PC) yang merupakan tanaman tebu tahun pertama, kepras 1 (tanaman tahun kedua), kepras 2 (tanaman tahun ketiga), dan kepras 3 (tanaman tahun keempat). 
Menurut PTPN VII Distrik Bungamayang (2018), dalam enam tahun terakhir, produktivitas gula atau hablur tebu rakyat yang ada di Kecamatan Bungamayang cenderung menurun. Rendahnya produktivitas menyebabkan menurunnya pendapatan dari usahatani tersebut. Besarnya pendapatan yang diterima petani akan memengaruhi pola konsumsi atau pengeluaran yang dilakukan oleh rumah tangga. Tingkat pengalokasian pendapatan terhadap pengeluaran rumah tangga kemudian akan memengaruhi tingkat kesejahteraan rumah tangga petani tersebut. Pada tahun 2017, sebanyak 23,39 persen dari jumlah keseluruhan keluarga di Kecamatan Bungamayang termasuk ke dalam golongan keluarga prasejahtera (BPS Kabupaten Lampung Utara 2018).

Tentu hal ini menjadi sebuah pertanyaan, ternyata subsektor perkebunan yang menjadi mata pencaharian utama mereka masih belum dapat menjamin keberlangsungan hidup untuk taraf yang lebih baik. Berdasarkan permasalahan yang ada, penelitian ini bertujuan untuk menganalisis pendapatan usahatani, pendapatan rumah tangga, tingkat kesejahteraan, dan faktor-faktor yang memengaruhi tingkat kesejahteraan rumah tangga petani tebu rakyat di Kecamatan Bungamayang Kabupaten Lampung Utara.

\section{METODE PENELITIAN}

Metode yang digunakan adalah metode survei. Lokasi penelitian dilakukan secara sengaja (purposive) dengan pertimbangan Kecamatan Bungamayang merupakan sentra produksi tebu di Kabupaten Lampung Utara tetapi memiliki produktivitas hablur tebu yang cenderung menurun dalam enam tahun terakhir. Jumlah sampel dalam penelitian ini adalah 54 petani dari total populasi sebanyak 178 petani tebu rakyat.

Dilakukan penentuan proporsi sampel berdasarkan desa dan umur tanaman, sehingga diperoleh jumlah sampel untuk tanaman tebu kriteria PC, kepras 1, 2, dan 3 di Desa Negara Tulang Bawang secara berturut-turut adalah 4,3,5,dan 6. Sementara untuk Desa Sukamaju adalah 13, 5, 8, dan 10 sampel petani tebu rakyat. Penentuan petani responden dilakukan dengan menggunakan metode pengambilan stratified dan simple random sampling. Pengambilan sampel dilakukan dengan cara membagi populasi menjadi empat strata, yakni PC, kepras 1, 2, dan 3, kemudian sampel diambil secara acak sederhana dari setiap strata yang ada. Waktu pengumpulan data dilakukan pada bulan April hingga Mei 2019.
Data yang digunakan dalam penelitian ini adalah data primer dan data sekunder. Data primer diperoleh dari petani tebu rakyat sebagai responden melalui teknik wawancara dengan menggunakan kuesioner. Data sekunder diperoleh dari studi literatur dan dari lembaga-lembaga/instansi terkait, seperti BPS, PTPN VII Distrik Bungamayang dan Direktorat Jenderal Perkebunan.

Analisis pendapatan digunakan untuk melihat manfaat (keuntungan) dari suatu usaha, sehingga dapat dinilai tingkat kelayakan suatu usaha tersebut. Analisis data yang digunakan untuk menganalisispendapatan usahatani tebu rakyat adalah rumus menurut Soekartawi (1995).

$$
\begin{array}{ll}
\pi=\text { TR-TC }=(\mathrm{Y} . \mathrm{Py})-\left(\sum_{\mathrm{i}=1}^{\mathrm{n}} \mathrm{Xi} . \text { Pxi-BTT }\right) \ldots \ldots \ldots \ldots . . .(1) \\
\text { Keterangan : } \\
\pi \quad=\text { Pendapatan } \\
\mathrm{Y} & =\text { Hasil produksi }(\mathrm{kg}) \\
\mathrm{Py} & =\text { Harga hasil produksi }(\mathrm{Rp}) \\
\mathrm{Xi} & =\text { Faktor produksi ke-i } \\
\mathrm{Pxi} & =\text { Harga faktor produksi ke }-\mathrm{i}(\mathrm{Rp} / \text { Satuan }) \\
\mathrm{BTT} & =\text { Biaya tetap total } \\
\mathrm{i} & =1,2,3,4,5, \mathrm{n}
\end{array}
$$

Cara mengetahui apakah usahatani tebu tersebut menguntungkan atau merugikan, maka dilakukan analisis R/C. Analisis R/C merupakan perbandingan (ratio atau nisbah) antara penerimaan (revenue) dengan biaya (cost). Nilai R/C diperoleh menggunakan rumus Soekartawi (1995), yaitu:

$\mathrm{R} / \mathrm{C}=\frac{\mathrm{TR}}{\mathrm{TC}}=\frac{\mathrm{Y} \cdot \mathrm{Py}}{\sum_{\mathrm{i}=1}^{\mathrm{n}} \mathrm{Xi} \cdot \mathrm{Pxi}+\mathrm{BTT}}$.

$$
\begin{array}{ll}
\text { Keterangan : } \\
\mathrm{R} / \mathrm{C} \quad=\text { Revenue Cost } \\
\mathrm{Y} & =\text { Hasil produksi }(\mathrm{Kg}) \\
\mathrm{Py} & =\text { Harga hasil produksi }(\mathrm{Rp}) \\
\mathrm{Xi} & =\text { Faktor produksi ke-i } \\
\mathrm{Pxi} & =\text { Harga faktor produksi ke }-\mathrm{i}(\mathrm{Rp} / \text { Satuan }) \\
\mathrm{BTT} & =\text { Biaya tetap total }
\end{array}
$$

Kriteria pengambilan keputusan :

Jika $\mathrm{R} / \mathrm{C}<1$, maka usahatani yang dilakukan belum menguntungkan.

Jika $\mathrm{R} / \mathrm{C}>1$, maka usahatani yang dilakukan menguntungkan.

Jika $\mathrm{R} / \mathrm{C}=1$, maka usahatani yang dilakukan berada pada titik impas.

Pendapatan rumah tangga diperoleh dengan cara menjumlahkan pendapatan yang berasal dari usahatani (on farm), non usahatani (non farm), dan 
pendapatan di luar pertanian (non farm) (Rahim dan Hastuti 2008), dengan rumus sebagai berikut:

$\mathrm{P}_{\mathrm{RT}}=\mathrm{P}_{\text {off farm }}+\mathrm{P}_{\text {on farm }}+\mathrm{P}_{\text {non }}$

Keterangan:

$\begin{array}{ll}\mathrm{P}_{\mathrm{RT}} & =\text { Pendapatan rumah tangga petani tebu } \\ & \text { per tahun } \\ \mathrm{P}_{\text {off farm }}= & \text { Pendapatan pertanian dari luar } \\ & \text { budidaya tebu rakyat } \\ \mathrm{P}_{\text {onfarm }}= & \text { Pendapatan dari usahatani tebu rakyat } \\ \mathrm{P}_{\text {non farm }}= & \text { Pendapatan dari luar pertanian }\end{array}$

Tingkat kesejahteraan rumah tangga petani tebu rakyat diukur dengan menggunakan kriteria tingkat kemiskinan Sajogyo (1997) yang meninjau tingkat kesejahteraan melalui pendekatan pengeluaran rumah tangga. Secara matematis, tingkat pengeluaran per kapita per tahun pada rumah tangga petani dan tingkat pengeluaran per kapita per tahun setara beras dirumuskan sebagai berikut:

$\mathrm{C} /$ kapita $/$ th $(\mathrm{Rp})=\frac{\mathrm{c}}{\Sigma \text { keluarga }}$.

$\mathrm{C} /$ kapita / setara beras $(\mathrm{kg})=\frac{\frac{\mathrm{c}}{\text { kapita }} / \text { tahun }}{\text { harga beras }}$.

Keterangan:

$\mathrm{C}=$ Total pengeluaran rumah tangga

Klasifikasi kemiskinan menurut Sajogyo digolongkan ke dalam enam bagian antara lain:

1) Paling miskin, jika pengeluaran per anggota keluarga adalah $180 \mathrm{~kg}$ setara beras/tahun.

2) Miskin sekali, jika pengeluaran per anggota keluarga adalah 181-240 kg setara beras/tahun.

3) Miskin, jika pengeluaran per anggota keluarga adalah $241-320 \mathrm{~kg}$ setara beras/tahun.

4) Nyaris miskin, jika pengeluaran per anggota keluarga adalah 321-480 kg setara beras/tahun.

5) Cukup, jika pengeluaran per anggota keluarga adalah $481-960 \mathrm{~kg}$ setara beras/tahun.

6) Hidup layak, jika pengeluaran per anggota keluarga adalah $>960 \mathrm{~kg}$ setara beras/tahun.

Faktor-faktor yang memengaruhi tingkat kesejahteraan rumah tangga dianalisis dengan menggunakan analisis regresi binary logistic. Kriteria kesejahteraan Sajogyo 1, 2, 3, dan 4 dianggap menjadi kategori belum sejahtera (0). Sementara, kriteria kesejahteraan Sajogyo 5 dan 6 dianggap menjadi kategori sejahtera (1). Model analisis yang digunakan untuk menjawab tujuan iniadalah sebagai berikut:

$\mathrm{Zi}=\operatorname{Ln}\left[\frac{\mathrm{Pi}}{1-\mathrm{Pi}}\right]=\alpha+\beta_{1} \mathrm{X}_{1}+\beta_{2} \mathrm{X}_{2}+\beta_{3} \mathrm{X}_{3}+\beta_{4} \mathrm{X}_{4}+\mathrm{e}$.
Keterangan:

$\mathrm{Zi} \quad=$ Peluang tingkat kesejahteraan ( $0=$ belum sejahtera; 1 = sejahtera $)$

$\alpha \quad=$ Intersep

$\beta_{1} \ldots \beta_{4}=$ Koefisien regresi

$\mathrm{X} 1=$ Pendapatan rumah tangga $(\mathrm{Rp} / \mathrm{thn})$

$\mathrm{X} 2=$ Jumlah anggota keluarga (Jiwa)

$\mathrm{X} 3=$ Harga beras $(\mathrm{Rp} / \mathrm{kg})$

$\mathrm{X} 4=$ Harga gula natura $(\mathrm{Rp} / \mathrm{kg})$

$\mathrm{e} \quad=$ Error term

$\mathrm{Pi} \quad=$ Probabilitas

Estimasi model logit dilakukan uji serentak yaitudengan menggunakan Likelihood Ratio (LR). Likelihood Ratio (LR) berfungsi untuk menguji apakah semua slope koefisien regresi variabel independen secara bersama-sama mempengaruhi variabel dependen. H0 ditolak jika Probability Likelihood Ratio < $\alpha$, dan $\mathrm{H} 0$ diterima jika Probability Likelihood Ratio $>\alpha$. Selanjutnya, dilakukan uji parsial ( $\mathrm{Z}$ stat) yaitu dengan menggunakan Wald Test. H0 ditolak jika Probability Wald $<\alpha$, dan $\mathrm{H} 0$ diterima jika Probability Wald $>\alpha$.

\section{HASIL DAN PEMBAHASAN}

\section{Karakteristik Responden Petani Tebu Rakyat}

Mayoritas $(48,15 \%)$ petani tebu rakyat di Kecamatan Bungama yang berada pada usia 47-63 tahun. Tingkat pendidikan petani tebu rakyat tergolong rendah, yaitu mayoritas $(42,29 \%)$ hanya tamatan SD. Rata-rata luas lahan petani tebu seluruh kriteria (gabungan) adalah 1,10 hektar dan memiliki pengalaman berusahatani tebu selama 14,35 tahun. Varietas yang paling banyak digunakan adalah BM9605.

Mayoritas (40,58\%) petani tebu memiliki pekerjaan sampingan sebagai petani non tebu (ubi kayu, sawit, dan karet). Rata-rata jumlah anggota keluarga petani tebu rakyat adalah 4 jiwa. Sebesar 94,44 persen petani tebu status kepemilikan lahannya adalah milik sendiri. Mayoritas (46,30\%) petani tebu tidak pernah mengikuti penyuluhan pertanian. Keseluruhan modal petani tebu rakyat merupakan modal pinjaman dari bank umum dan PTPN VII Distrik Bungamayang bertindak sebagai avalis oftaker atau pihak yang menjamin kepada bank umum bahwa petani sanggup untuk melunasi seluruh hutangnya (paket pinjaman) di kemudian hari. 


\section{Biaya Usahatani Tebu Rakyat}

Biaya usahatani merupakan seluruh pengeluaran yang dikeluarkan petani pada saat melaksanakan usahataninya. Rincian total biaya yang digunakan pada usahatani tebu rakyat di Kecamatan Bungamayang disajikan pada Tabel 1 . Total biaya potongan adalah penjumlahan dari (total paket pinjaman modal + bunga modal + biaya karung + biaya penyusutan tetes). Biaya paket pinjaman modal tersebut berupa biaya perawatan, biaya saprodi, dan biaya tebang muat angkut (TMA). Biaya perawatan mencakupi biaya pestisida dan biaya tenaga kerja yang digunakan dalam menjalankan usahatani. Biaya saprodi mencakupi biaya bibit (khusus plant cane) dan biaya pupuk. Biaya TMA mencakupi biaya tenaga kerja untuk tebang dan muat serta biaya angkutan dari lahan menuju pabrik.

Besar paket pinjamandari PTPN VII Distrik Bungamayang yang didapatkan oleh petani tebu disesuaikan dengan luasan lahan yang dimiliki. Paket pinjaman untuk biaya bibit sebesar Rp5.060.000,00/ha. Paket pinjaman untuk biaya pupuk sebesar Rp5.450.000,00/ha (PC) dan Rp4.200.000,00/ha (keprasan). Paket untuk biaya TMA ditentukan sesuai dengan jumlah produksi tebu yang dihasilkan, yakni Rp88.300,00/ton. Paket pinjaman untuk biaya perawatan yang mencakupi biaya pestisida dan TKLK selain TMA adalah sebesar Rp4.610.000,00/ha (PC) dan Rp3.360.000,00/ha (keprasan). Pinjaman modal dikenakan biaya bunga pinjaman sebesar masingmasing 6 persen.
Tabel 2. Produksi usahatani tebu rakyat per hektar di Kecamatan Bungamayang

\begin{tabular}{lrrrrr}
\hline \multicolumn{1}{c}{ Uraian } & \multicolumn{1}{c}{ PC } & \multicolumn{1}{c}{ K1* } & \multicolumn{1}{c}{ K2* } & \multicolumn{1}{c}{$\mathrm{K}^{*}$} & \multicolumn{1}{c}{$\mathrm{G}^{*}$} \\
\hline Tebu $(\mathrm{kg})$ & 91.558 & 88.651 & 79.487 & 77.833 & 83.895 \\
Rnd $(\%)$ & 7,21 & 6,76 & 6,82 & 6,81 & 6,93 \\
Gula a $(\mathrm{kg})$ & 3.917 & 3.486 & 3.284 & 3.132 & 3.459 \\
Gula b $(\mathrm{kg})$ & 435 & 387 & 364 & 348 & 384 \\
Tetes $(\mathrm{kg})$ & 2.747 & 2.659 & 2.384 & 2.335 & 2.516 \\
\hline
\end{tabular}

Keterangan: *) K1: Keprasan 1, K2: Keprasan 2,

K3: Keprasan 3, G: Gabungan,

Rnd: Rendemen, Gula a: Gula (90\%),

Gula b: Gula (10\%)

\section{Produksi Usahatani Tebu Rakyat}

Produksi adalah kegiatan yang mengubah input menjadi output. Produksi petani tebu rakyat dalam penelitian ini terdiri dari produksi gula dan tetes. Jumlah produksi yang dihasilkan dihitung dalam satuan kilogram. Rata-rata produksi petani tebu rakyat disajikan pada Tabel 2. Produksi gula diperoleh melalui perkalian antara jumlah ton tebu, tingkat rendemen, faktor perusahaan $(1,003)$ dan sistem bagi hasil yang diterapkan. Produksi tetes diperoleh melalui jumlah ton tebu dikalikan dengan 3 persen. Terdapat dua jenis produksi gula, yakni gula 90 persen dan gula 10 persen. Produksi gula 90 persen adalah jumlah 90 persen dari total produksi gula yang penjualannya dilakukan melalui perantara PTPN VII Distrik Bungamayang dengan cara pelelangan gula, sedangkan produksi gula 10 persen adalah jumlah 10 persen dari total produksi gula dan dijual sendiri oleh petani kepada pemborong tanpa melalui perantara perusahaan.

Tabel 1. Biaya usahatani tebu rakyat per hektar di Kecamatan Bungamayang

\begin{tabular}{lrrrrr}
\hline \multicolumn{1}{c}{ Jenis Biaya } & Plant Cane $(\mathrm{PC})$ & \multicolumn{1}{c}{ Keprasan 1 } & \multicolumn{1}{c}{ Keprasan 2 } & Keprasan 3 & Gabungan \\
\hline Biaya Tunai & & & & & \\
Bibit & 5.062 .781 & - & - & - & 1.550 .370 \\
Pupuk & 5.452 .996 & 4.213 .816 & 4.191 .268 & 4.187 .977 & 4.597 .138 \\
Pestisida & 596.797 & 599.753 & 589.345 & 575.644 & 590.438 \\
TKLK & 11.769 .202 & 10.418 .372 & 9.772 .356 & 9.580 .612 & 10.425 .088 \\
Sewa Lahan & - & - & 77.963 & 122.853 & 62.290 \\
Pajak Lahan & 24.013 & 24.079 & 23.534 & 23.302 & 23.758 \\
Biaya Karung & 319.533 & 284.308 & 267.893 & 225.474 & 282.178 \\
Penyusutan Tetes & 85.919 & 83.164 & 74.567 & 73.016 & 78.702 \\
Biaya Bunga & 1.392 .936 & 924.767 & 873.780 & 864.666 & 1.038 .588 \\
Total Biaya Tunai & 24.704 .180 & 16.548 .258 & 15.870 .707 & 15.683 .543 & 18.648 .549 \\
Total Biaya Potongan & 25.013 .991 & 16.705 .018 & 15.779 .241 & 15.604 .254 & 18.709 .269 \\
Biaya Diperhitungkan & & & & & \\
Sewa Lahan & & & & & \\
TKDK & 4.817 .207 & 4.950 .658 & 5.000 .000 & 4.859 .256 & 4.911 .195 \\
$\quad$ Penyusutan Alat & 107.201 & 287.829 & 181.428 & 161.975 & 163.519 \\
Total Biaya Diperhitungkan & 377.739 & 796.552 & 576.238 & 407.111 & 480.846 \\
Total Biaya & 5.302 .148 & 6.035 .038 & 5.757 .665 & 5.428 .342 & 5.555 .560 \\
\hline
\end{tabular}




\section{Pendapatan Usahatani Tebu Rakyat}

Pendapatan usahatani tebu rakyat diperoleh dari hasil pengurangan antara total penerimaan dengan total biaya. Diketahui bahwa usahatani tebu di Kecamatan Bungamayang merupakan bagian dari program Tebu Rakyat Intensifikasi (TRI) PTPN VII Distrik Bungamayang, sehingga seluruh petani tebu mengikuti kemitraan dan mendapatkan pinjaman modal, bimbingan teknis, serta dikenakan sistem bagi hasil. Penerimaan petani tebu rakyat menurut PTPN VII Distrik Bungamayang dirumuskan sebagai berikut:

Penerimaan $=((($ Jumlah total produksi tebu $\mathrm{X}$ Rendemen X 1,003 X Sistem bagi hasil $X \quad 90 \%) \quad X$ Harga gula perusahaan $+($ Jumlah total produksi tebu X 3\% X Harga tetes) + ( Jumlah produksi gula $10 \% \mathrm{X}$ Harga gula yang diterima)))

Harga yang diterima petani tebu rakyat adalah harga yang sudah menjadi keputusan bersama dalam Forum Musyawarah Produksi Gula (FMPG). Gula 90 persen dihargai Rp10.300,00/kg dan tetes tebu dihargai Rp1.100,00/kg. Berbeda dengan gula 10 persen atau biasa disebut dengan gula natura, harga ditentukan oleh kesepakatan antara petani dan pembeli. Hasil penelitian menunjukkan harga gula natura yang diterima petani tebu rakyat di Kecamatan Bungamayang berada pada kisaran Rp11.000,00-Rp12.500,00/kg dengan rata-rata sebesar Rp11.448,61/kg.

Sistem bagi hasil gula untuk petani tebu rakyatdidasarkan pada tingkat rendemen yang dimiliki. Sistem bagi hasil gulaantara petani dengan perusahaan dirumuskansebagai berikut:

Rendemen $\leq 0,07=0,66$ petani, 0,34 perusahaan

Rendemen $>0,07=0,68$ petani, 0,32 perusahaan
Biaya insentif diperoleh dari 5,5 persen pendapatan kotor, dimana pendapatan kotor didapatkan dari hasil pengurangan antara total penerimaan dengan total potongan. Setelah diketahui besarnya biaya insentif, maka dapat ditentukan pendapatan bersih usahatani tebu rakyat yang dirumuskan perusahaan sebagai berikut:

Pendapatan bersih atas biaya tunai $=$

(Penerimaan - Biaya Tunai) - Biaya Insentif)

Pendapatan bersih atas biaya total $=$ (Penerimaan - Total Biaya) - Biaya Insentif) Ringkasan dari penerimaan, biaya, dan R/C usahatani tebu rakyat disajikan pada Tabel 3.

Hasil penelitian menunjukkan seluruh R/C usahatani tebu rakyat kriteria PC, kepras 1 , kepras 2, kepras 3, dan juga gabungan berada di atas angka 1. Berdasarkan hal itu, dapat disimpulkan bahwa usahatani tebu rakyat yang diusahakan oleh petani tebu di Kecamatan Bungamayang menguntungkan. Pendapatan per hektar tertinggi terdapat pada kriteria tebu kepras 1 , begitu juga dengan nilai $\mathrm{R} / \mathrm{C}$, nilai $\mathrm{R} / \mathrm{C}$ tertinggi terdapat pada kriteria tebu kepras 1 . Hasil penelitian ini sejalan dengan penelitian Pranoto, Lestari, dan Murniati (2017), yang menyatakan bahwa pendapatan per hektar dan nilai R/C petani tebu kriteria kepras 1 lebih besar dibandingkan dengan kriteria lainnya.

Apabila dilihat secara keseluruhan kriteria (gabungan), pendapatan per hektar atas biaya tunai dan total petani teburakyat hampir sama dengan kriteria plant cane (PC), namun jika ditinjau dari nilai $\mathrm{R} / \mathrm{C}, \mathrm{R} / \mathrm{C}$ per hektar atas biaya tunai dan total petani tebu seluruh kriteria (gabungan) lebih mendekati dengan kriteria kepras 3. Hasil penelitian ini sejalan dengan penelitian Gustiana (2017), yang menyatakan bahwa R/C per hektar atas biaya tunai dan total petani tebu rakyat secara keseluruhan kriteria (gabungan) lebih mendekati dengan kriteria kepras 3.

Tabel 3. Pendapatan usahatani tebu rakyat per hektar di Kecamatan Bungamayang

\begin{tabular}{lrrrrr}
\hline \multicolumn{1}{c}{ Keterangan } & \multicolumn{1}{c}{ Plant Cane } & \multicolumn{1}{c}{ Keprasan 1 } & \multicolumn{1}{c}{ Keprasan2 } & \multicolumn{1}{c}{ Keprasan 3 } & \multicolumn{1}{c}{ Gabungan } \\
\hline Penerimaan & 48.300 .798 & 43.310 .612 & 40.662 .992 & 38.828 .349 & 42.807 .249 \\
Biaya Tunai & 24.704 .181 & 16.548 .258 & 15.870 .706 & 15.683 .543 & 18.648 .549 \\
Biaya Diperhitungkan & 5.302 .148 & 6.035 .038 & 5.757 .665 & 5.428 .341 & 5.555 .560 \\
Total Biaya & 30.006 .329 & 22.583 .297 & 21.628 .372 & 21.111 .885 & 24.204 .109 \\
Total Biaya Potongan* & 25.013 .991 & 16.705 .018 & 15.779 .241 & 15.604 .254 & 18.709 .269 \\
Pendapatan Kotor Atas Biaya Tunai & 15.341 .285 & 19.201 .472 & 18.054 .168 & 16.660 .639 & 16.928 .141 \\
Biaya Insentif & 843.771 & 1.056 .081 & 992.979 & 916.335 & 931.047 \\
Pendapatan Bersih Atas Biaya Tunai & 22.730 .986 & 25.647 .912 & 23.704 .094 & 22.152 .482 & 23.161 .313 \\
Pendapatan Bersih Atas Biaya Total & 17.428 .838 & 19.612 .873 & 17.946 .428 & 16.724 .140 & 17.605 .753 \\
R/C Atas Biaya Tunai & 1,96 & 2,62 & 2,56 & 2,48 & 2,30 \\
R/C Atas Biaya Total & 1,61 & 1,92 & 1,88 & 1,84 & 1,77 \\
\hline K & & & & &
\end{tabular}

Keterangan: * Total potongan hanya digunakan untuk perhitungan biaya insentif 


\section{Pendapatan Rumah Tangga Petani Tebu Rakyat}

Sumber-sumber pendapatan rumah tangga petani tebu rakyat di Kecamatan Bungamayang terbagi menjadi tiga bagian yaitu pendapatan usahatani tebu dan non tebu (on farm), pendapatan pertanian diluar budidaya (off farm), dan pendapatan di luar bidang pertanian (non farm). Pendapatan usahatani non tebu bersumber dari usahatani ubi kayu, kelapa sawit, dan karet. Petani tebu rakyat yang mengusahakan usahatani ubi kayu berjumlah 40,74 persen, sedangkan petani yang mengusahakan usahatani kelapa sawit dan karet jumlahnya samasama sebesar 9,26 persen. Rata-rata luas lahan usahatani ubi kayu, sawit, dan karet yang diusahakan petani tebu rakyat secara berturut-turut adalah 0,$19 ; 0,07$; dan 0,06 ha. Pendapatan off farm petani tebu rakyat bersumber dari pendapatan sebagai buruh tani. Sebesar 20,37persen petani tebu rakyat menjadikan pekerjaan buruh tani di usahatani petani lain untuk menambah pendapatan rumah tangganya. Pendapatan non farm bersumber dari berbagai macam jenis pekerjaan antara lain, sebesar 11,11 persen petani menjadi buruh non pertanian (bangunan).

Sebesar 3,70 persen petani memiliki bengkel motor, sebesar 20,37 persen petani memiliki warung skala kecil hingga menengah, dan sebesar 5,50 persen petani memiliki usaha rumah makan, serta terdapat pula sebesar 3,70 persen petani yang menjadikan gaji pensiunan PTPN VII Distrik Bungamayang sebagai pendapatan non farm-nya. Kontribusi dari 3 jenis sumber pendapatan terhadap pendapatan rumah tangga disajikan pada Tabel 4. Berdasarkan data dari Tabel 4, terlihat bahwa kontribusi terbesar dalam pendapatan rumah tangga petani tebu rakyat di Kecamatan Bungamayang adalah pada kegiatan on farm, yakni sebesar 79,71 persen. Tingginya kontribusi sektor pertanian (on farm) terhadap total pendapatan rumah tangga ini sejalan dengan penelitian yang telah dilakukan sebelumnya, dimana Gusti, Haryono, dan Prasmatiwi (2013) menyatakan bahwa pendapatan sektor pertanian memiliki kontribusi paling besar terhadap total pendapatan rumah tangga petani perkebunan di Kecamatan Padang Cermin Kabupaten Pesawaran. Kegiatan on farmyang diusahakan oleh petani tebu rakyat terdiri dari usahatani tebu itu sendiri dan usahatani non tebu, dimana kontribusi usahatani tebu rakyat memiliki persentase lebih besar dibandingkan dengan usahatani non tebu, yakni sebesar 57,52 persen.
Tabel 4. Kontribusi sumber-sumber pendapatan terhadap pendapatan total petani tebu rakyat di Kecamatan Bungamayang

\begin{tabular}{lrr}
\hline No $\quad$ Sumber Pendapatan & $\begin{array}{c}\text { Pendapatan } \\
\text { (Rp/thn) }\end{array}$ & \multicolumn{1}{c}{$(\%)$} \\
\hline 1. On farm : & 35.308 .927 & 79,71 \\
a) Usahatani tebu (1,10 ha) & 25.477 .445 & 57,52 \\
b) Usahatani non tebu: & & \\
$\quad$ Ubi kayu (0,19 ha) & 5.697 .315 & 12,86 \\
$\quad$ Kelapa sawit (0,07 ha) & 2.423 .796 & 5,47 \\
$\quad$ Karet (0,06 ha) & 1.710 .370 & 3,86 \\
& & \\
& 1.386 .666 & 3,13 \\
2. Off farm & 1.386 .666 & 3,13 \\
$\quad$ Buruh tani & 7.600 .000 & 17,16 \\
& 470.000 & 1,06 \\
3. Non farm & 888.889 & 2,01 \\
$\quad$ Buruh non pertanian & 3.655 .556 & 8,25 \\
$\quad$ Pemilik bengkel & 1.833 .333 & 4,14 \\
$\quad$ Pemilik warung/pedagang & 752.222 & 1,70 \\
$\quad$ Pemilik rumah makan & 44.295 .593 & 100,00 \\
$\quad$ Pensiunan PTPN VII & 3.691 .299 & \\
\hline Total (Rp) & 909.909 & \\
Rerata pendapatan/bln (Rp) & & \\
\hline Rerata pendapatan/kapita/bln (Rp) &
\end{tabular}

Hal ini menunjukkan bahwa sektor perkebunan tebu merupakan pendapatan utama bagi masyarakat di Kecamatan Bungamayang dan masih memegang peranan penting dalam menjaga keberlangsungan hidup petani tebu rakyat. Hasil penelitian ini sejalan dengan penelitian Rohmah, Suryantini, dan Hartono (2014) yang menyatakan bahwa kontribusi pendapatan usahatani tebu memiliki kontribusi paling besar terhadap total pendapatan rumah tangga petani tebu tanam dan keprasan di Kabupaten Bantul.

\section{Analisis Tingkat Kesejahteraan Rumah Tangga}

Pengukuran tingkat kesejahteraan rumah tangga berdasarkan kriteria Sajogyo (1997) dilakukan dengan menghitung pengeluaran per kapita per tahun menggunakan rata-rata harga beras per kilogram yang digunakan oleh petani responden. Pengeluaran petani tebu rakyat terdiri dari pengeluaran pangan dan non pangan. Selisih proporsi pengeluaran pangan dan non pangan per tahun tergolong kecil, yakni hanya sebesar 2,04 persen. Proporsi jenis pengeluaran terhadap total pengeluaran rumah tangga disajikan pada Tabel 5 . Pengeluaran petani tebu rakyat untuk kebutuhan pangan lebih besar dibandingkan non pangannya. Penelitian ini sejalan dengan penelitian Mardiana, Abidin, dan Soelaiman (2014) yang menyatakan bahwa pengeluaran pangan petani perkebunan lebih besar dibandingkan dengan non pangannya. 
Tabel 5. Proporsi pengeluaran pangan dan nonpangan terhadap total pengeluaran rumah tangga petani tebu rakyatdi Kecamatan Bungamayang

\begin{tabular}{lrrr}
\hline No $\quad$ Pengeluaran & Per Bulan & Per Tahun & Proporsi \\
\hline 1. Pangan & 1.556 .347 & 18.668 .832 & 51,02 \\
2. Non pangan & 1.500 .429 & 17.920 .000 & 48,98 \\
\hline Total Pengeluaran & 3.056 .776 & 36.588 .832 & 100,00 \\
\hline Pengeluaran/kapita & 744.206 & 8.932 .180 & \\
\hline
\end{tabular}

Pengeluaran rumah tangga akan memengaruhi tingkat kesejahteraan petani. Tingkat kesejahteraan rumah tangga diperoleh dari pengeluaran rumah tangga per kapita per tahun. Pengeluaran rumah tangga per kapita per tahun adalah total pengeluaran rumah tangga petani, baik pengeluaran pangan maupun non pangan dalam setahun dibagi jumlah anggota keluarga.

Total pengeluaran rumah tangga kemudian dikonversikan ke dalam ukuran setara beras per kilogram dengan cara membagi pengeluaran per kapita per tahun dengan rata-rata harga beras. Rata-rata harga beras yang dikeluarkan oleh petani tebu rakyat di Kecamatan Bungamayang adalah sebesar Rp11.185,19/kg. Cara untuk melihat tingkat kesejahteraan rumah tangga petani tebu rakyat adalah dengan menggolongkan pengeluaran setara beras tersebut ke dalam enam golongan. Sebaran golongan tingkat kesejahteraan petani tebu rakyat disajikan pada Tabel 6 .

Berdasarkan Tabel 6 terlihat bahwa rumah tangga petani tebu rakyat di Kecamatan Bungamayang yang tergolong kategori nyaris miskin adalah sebesar 16,67 persen, kategori cukup sebesar 55,56 persen, dan kategori hidup layak sebesar 27,78 persen. Berdasarkan hal tersebut, dapat disimpulkan mayoritas rumah tangga petani tebu rakyat di Kecamatan Bungamayang tergolong ke dalam kesejahteraan rumah tangga cukup.

Tabel 6. Sebaran golongan tingkat kesejahteraan petani tebu rakyat di Kecamatan Bunga mayang menurut Kriteria Sajogyo

\begin{tabular}{|c|c|c|c|c|}
\hline No & Golongan & Interval Skor & $\begin{array}{c}\text { Jumlah } \\
\text { (RT) }\end{array}$ & $\begin{array}{c}\text { Persentase } \\
(\%)\end{array}$ \\
\hline & Paling Miskin & $<180 \mathrm{~kg}$ & 0 & 0,00 \\
\hline 2. & Miskin Sekali & $181-240 \mathrm{~kg}$ & 0 & 0,00 \\
\hline 3. & Miskin & $241-320 \mathrm{~kg}$ & 0 & 0,00 \\
\hline 4. & Nyaris Miskin & $321-480 \mathrm{~kg}$ & 9 & 16,67 \\
\hline 5. & Cukup & $481-960 \mathrm{~kg}$ & 30 & 55,56 \\
\hline 6. & Hidup Layak & $>960 \mathrm{~kg}$ & 15 & 27,78 \\
\hline \multicolumn{3}{|c|}{ Total } & 54 & 100,00 \\
\hline
\end{tabular}

Hasil penelitian ini sejalan dengan penelitian Khasanah (2018) yang menyatakan bahwa mayoritas $(90,74 \%)$ petani responden di Kecamatan Sidomulyo Kabupaten Lampung Selatan tergolong ke dalam kesejahteraan cukup.

\section{Analisis Faktor-Faktor yang Memengaruhi Tingkat Kesejahteraan Rumah Tangga Petani}

Variabel terikat (Y) pada penelitian ini adalah kesejahteraan rumah tangga petani tebu rakyat mengacu pada kriteria kesejahteraan Sajogyo (1997) yang diukur berdasarkan pengeluaran pangan dan non pangan rumah tangga selama satu tahun. Pada penelitian ini, kriteria kesejahteraan Sajogyo 1, 2, 3, dan 4 dianggap menjadi kategori belum sejahtera (0). Sementara kriteria kesejahteraan Sajogyo 5 dan 6 dianggap menjadi kategori sejahtera (1). Variabel bebas (X) pada penelitian adalah pendapatan rumah tangga (X1), jumlah anggota keluarga (X2), harga beras (X3), dan harga gula natura (X4). Hasil uji logistik penelitian ini disajikan pada Tabel 7 .

Tabel 7 menunjukkan bahwa nilai Mcfadden Rsquared sebesar 0,849796 artinya bahwa 84,97 persen variasi peluang petani tebu rakyat untuk hidup sejahtera dapat dijelaskan oleh variabel yang terdapat di dalam model, yaitu pendapatan rumah tangga, jumlah anggota keluarga, harga beras, dan harga gula natura. Sisanya, sebesar 15,03 persen dijelaskan oleh variabel-variabel lain yang tidak dimasukkan ke dalam model. Nilai LR statistik pada penelitian ini sebesar 41,35160 dan nilai probability LR statistik sebesar $0,000000<0,01$. Artinya variabel pendapatan rumah tangga, jumlah anggota keluarga, harga beras, dan harga gula natura secara bersama-sama berpengaruh nyata terhadap peluang petani tebu rakyat untuk hidup sejahtera dengan tingkat kepercayaan sebesar 99 persen.

Tabel 7. Hasil regresi faktor yang memengaruhi kesejahteraan rumah tangga petani tebu rakyat di Kecamatan Bungamayang

\begin{tabular}{cccccc}
\hline Variabel & TH & Coefficient & Z-Statistic & Prob. & $\begin{array}{c}\text { Odd- } \\
\text { Ratio }\end{array}$ \\
\hline Constant & $-6,224622$ & $-0,14639$ & 0,8836 & 0,0019 \\
X1 & + & $9,60 \mathrm{E}-07^{*}$ & 1,916477 & 0,0553 & 1,0000 \\
X2 & - & $-4,665208^{*}$ & $-1,763328$ & 0,0778 & 0,0094 \\
X3 & - & $-6,51 \mathrm{E}-05$ & $-0,054965$ & 0,9562 & 0,9999 \\
X4 & + & 0,000111 & 0,036562 & 0,9708 & 1,0001 \\
\hline LR statistic & 41,35160 & Mc Fadden & \\
Prob.LR & 0,000000 & R-squared & 0,84979 \\
\hline
\end{tabular}

Keterangan: * Taraf kepercayaan 90 persen

TH: Tanda Harapan 
Variabel jumlah anggota keluarga memiliki nilai z statistik sebesar -1,763328 dengan probabilitas 0,0778 , artinya variabel jumlah anggota keluarga berpengaruh nyata terhadap peluang petani tebu rakyat untuk hidup sejahtera dengan tingkat kepercayaan sebesar 90 persen. Hasil penelitian ini sejalan dengan penelitian Aniri dan Hartoyo (2008), yang menyatakan jumlah anggota keluarga berpengaruh nyata terhadap tingkat kesejahteraan. Variabel pendapatan rumah tangga memiliki nilai z-statistik sebesar 1,916477 dengan probabilitas 0,0553 artinya variabel pendapatan rumah tangga berpengaruh nyata terhadap peluang petani tebu rakyat untuk hidup sejahtera dengan tingkat kepercayaan sebesar 90 persen. Hal ini sejalan dengan penelitian Pranata (2018) yang menyatakan bahwa pendapatan rumah tangga berpengaruh nyata terhadap tingkat kesejahteraan.

\section{KESIMPULAN}

Usahatani tebu rakyat di Kecamatan Bungamayang Kabupaten Lampung Utara menguntungkan. Ratarata pendapatan rumah tangga petani tebu rakyat sebesar Rp44.295.593/tahun yang bersumber dari pendapatan on farm, off farm, dan non farm. Berdasarkan kriteria Sajogyo (1997), sebagian besar tingkat kesejahteraan rumah tangga petani tebu rakyat termasuk dalam kategori cukup. Faktor-faktor yang berpengaruh terhadap tingkat kesejahteraan rumah tangga petani tebu rakyat adalah jumlah anggota keluarga dan pendapatan rumah tangga.

\section{DAFTAR PUSTAKA}

Aniri NB dan Hartoyo. 2008. Analisis tingkat kesejahteraan keluarga pembudidaya ikan dan nonpembudidaya ikan di Kabupaten Bogor. JIKK, 3(1): 64-73. http://journal.ipb. ac.id/index.php/jikk/article/view/5185. [20 Mei 2019].

Badan Pusat Statistik. 2018. Statistik Indonesia 2018. http://www.bps.go.id. [12 Desember 2018].

Badan Pusat Statistik Kabupaten Lampung Utara. 2018. Lampung Utara Dalam Angka 2018. http://lampungutara.bps.go.id. [15 Oktober 2018].

Direktorat Jenderal Perkebunan. 2017. Statistik Perkebunan Indonesia 2017. http://ditjenbun.pertanian.go.id. November 2018]

Gusti AI, Haryono D, dan Prasmatiwi FE. 2013. Pendapatan rumah tangga petani kakao di Desa Pesawaran Indah Kecamatan Padang
Cermin Kabupaten Pesawaran. Jurnal Ilmu Ilmu Agribisnis, 1(4): 278-283. http://jurnal.fp.unila.ac.id/index. php/JIA/article/view/701. [16 April 2019].

Gustiana E. 2017. Analisis Pendapatan dan Distribusi Pendapatan Usahatani Tebu Rakyat di Kecamatan Bungamayang Kabupaten Lampung Utara. Skripsi. Jurusan Agribisnis Universitas Lampung. Bandar Lampung.

Hudaya D. 2009. Faktor-Faktor yang Memengaruhi Kemiskinan di Indonesia. Skripsi. Departemen Ilmu Ekonomi IPB. Bogor.

Khasanah WN. 2018. Pendapatan dan Kesejahteraan Rumah Tangga Petani Padi Ladang di Kecamatan Sidomulyo Kabupaten Lampung Selatan. Skripsi. Jurusan Agribisnis Universitas Lampung. Bandar Lampung.

Mardiana R, Abidin Z, dan Soelaiman A. 2014. Pendapatan dan kesejahteraan petani karet di Kecamatan Bumi Agung Kabupaten Way Kanan. Jurnal Ilmu Ilmu Agribisnis, 2(3): 239-245. http://jurnal.fp. unila.ac.id/ index. php/JIA /article/view/806. [10 Agustus 2019].

Pranata Y. 2018. Pendapatan dan Kesejahteraan Rumah Tangga Petani Lada di Kecamatan Tanjung Raja Kabupaten Lampung Utara. Skripsi. Jurusan Agribisnis Universitas Lampung. Bandar Lampung.

Pranoto IL, Lestari DAH, dan Murniati K. 2017. Evaluasi kemitraan antara petani tebu dan PT Perkebunan Nusantara VII Distrik Bungamayang, Kecamatan Bungamayang, Kabupaten Lampung Utara. Jurnal Ilmu Ilmu Agribisnis, $\quad$ 5(4): 376-383. http://jurnal.fp.unila.ac.id/index.php /JIA/article/view/1746. [25 Juni 2019].

PTPN VII Distrik Bungamayang. 2018. Lampiran Produksi dan Rendemen Tahun 2012-2017 di Kecamatan Bungamayang. Tidak dipublikasikan.

Rahim A dan Hastuti DRW. 2008. Ekonomi Pertanian. Penebar Swadaya. Jakarta.

Rohmah W, Suryantini A, dan Hartono S. 2014. Analisis pendapatan dan tingkat kesejahteraan rumah tangga petani tebu tanam dan keprasan di Kabupaten Bantul. Jurnal Agro Ekonomi, 24(1): 55-65. https:// jurnal.ugm.ac.id/jae/article/view/17382. [08 Juli 2019].

Sajogyo T. 1997. Garis Kemiskinan dan Kebutuhan Minimum Pangan. LPSB-IPB. Bogor.

Soekartawi. 1995. Analisis Usahatani. Raja Grafindo Persada. Jakarta. 